\title{
Phylogenetic Relationships Among the Methylotrophic Methane- Producing Bacteria and Emendation of the Family Methanosarcinaceae
}

\author{
KEVIN R. SOWERS, * JOHN L. JOHNSON, AND JAMES G. FERRY \\ Department of Anaerobic Microbiology, Virginia Polytechnic Institute and State University, Blacksburg, Virginia 24061
}

\begin{abstract}
The phylogenetic relationships among seven strains of methylotrophic methane-producing bacteria were determined by ribosomal ribonucleic acid hybridization and deoxyribonucleic acid homology techniques. The strains tested had deoxyribonucleic acid guanine-plus-cytosine contents of 39 to $43 \mathrm{~mol} \%$ and represented a diversity of phenotypic characteristics. Our results indicate that these strains should be divided into six species within the genera Methanosarcina, Methanolobus, and Methanococcoides. The genus Methanosarcina includes Methanosarcina barkeri strains MS and 227, Methanosarcina sp. strain TM-1, Methanosarcina acetivorans strain C2A, and Methanosarcina mazei strain S-6. The genus Methanolobus is represented by Methanolobus tindarius strain Tindari 3, and the genus Methanococcoides is represented by Methanococcoides methylutens strain TMA-10. Despite phenotypic similarities between Methanolobus tindarius and Methanococcoides methylutens, we propose that these species remain in separate genera based on differences in ribosomal ribonucleic acid homology and fractional differences in midpoint temperatures. The divisions indicated by deoxyribonucleic acid homology experiments complemented the ribosomal ribonucleic acid hybridization results. Phenotypic characteristics were consistent with these phylogenetic divisions; an apparent exception was cell wall composition, which is a conserved trait. Methanosarcina acetivorans had only a thin protein cell wall, but all other strans of Methanosarcina previously studied have been reported to have heteropolysaccharide cell walls. We present evidence which indicates that a protein component may be associated with the heteropolysaccharide cell wall of Methanosarcina barkeri strain 227.
\end{abstract}

The methane-producing bacteria belong to the archaeobacteria, which, based on 16 S oligonucleotide cataloging (6), are phylogenetically distinct from the eubacteria and eucaryotes. The most comprehensive phylogenetic study of the methanogenic bacteria was done by Balch et al. (1), who proposed the presently accepted divisions among this group. In that study, the Methanosarcinaceae, the only methanogenic family with methylotrophic species, was represented by three strains of one species. Since then, several methylotrophic methane-producing species have been described. These include Methanosarcina mazei (17), Methanothrix soehngenii (8), Methanolobus tindarius (15), Methanococcoides methylutens (26), and Methanosarcina acetivorans (25a). The taxonomic positions of only Methanothrix soehngenii (27) and Methanosarcina mazei (17) are phylogenetically classified by $16 \mathrm{~S}$ ribosomal ribonucleic acid (rRNA) oligonucleotide cataloging; the other taxa are based on phenotypic characteristics and guanine-plus-cytosine $(G+C)$ contents of deoxyribonucleic acids (DNAs). Another isolate, Methanosarcina sp. strain TM-1, also has been described (35), but a specific epithet has not been proposed. The electrophoretic patterns of ribosomal proteins suggest that there are important phylogenetic differences between phenotypically similar strains of Methanosarcina that may not be detected by rRNA oligonucleotide cataloging (5). Although the methanogenic bacteria have been previously studied by rRNA hybridization techniques, only one methylotrophic strain was included in that study (29). In this study the phylogenetic relationships of seven strains of methylotrophic methane-producing bacteria were determined by rRNA hybridization and DNA reassociation techniques, and taxonomic divisions are proposed.

\footnotetext{
* Corresponding author.
}

\section{MATERIALS AND METHODS}

Bacterial strains. Methanosarcina barkeri strain MS (= DSM 800) was obtained from M. P. Bryant. Methanosarcina barkeri strain 227 (= DSM 1538), Methanosarcina sp. strain TM-1 (= DSM 1825), and Methanosarcina mazei strain S-6 (= DSM 2053) were obtained from R. A. Mah. Methanolobus tindarius strain Tindari 3 (= DSM 2278) was obtained from K. O. Stetter. Methanococcoides methylutens strain TMA-10 (= DSM 2657) and Methanosarcina acetivorans strain C2A (= DSM 2834) have been described previously (25a, 26).

Media and growth conditions. Sterile media were prepared anaerobically in an atmosphere containing $\mathrm{N}_{2}$ and $\mathrm{CO}_{2}$ $(80: 20)(7)$. Gases were passed through a column of reduced copper filings at $350^{\circ} \mathrm{C}$ to remove traces of $\mathrm{O}_{2}$. Nonmarine strains were maintained on agar slants of MPB medium that contained the following constituents in demineralized water (in final concentrations, wt/vol): $\mathrm{Na}_{2} \mathrm{CO}_{3}, 0.3 \% ; \mathrm{NH}_{4} \mathrm{Cl}$, $0.14 \% ; \mathrm{K}_{2} \mathrm{HPO}_{4}, 0.13 \% ; \mathrm{KH}_{2} \mathrm{PO}_{4}, 0.13 \% ; \mathrm{NaCl}, 0.05 \%$; $\mathrm{MgSO}_{4}, 0.05 \%$; cysteine hydrochloride $\cdot \mathrm{H}_{2} \mathrm{O}, 0.027 \%$; $\mathrm{Na}_{2} \mathrm{~S} \cdot 9 \mathrm{H}_{2} \mathrm{O}, \quad 0.027 \% ; \mathrm{CaCl}_{2} \cdot 2 \mathrm{H}_{2} \mathrm{O}, 0.006 \%$; $\mathrm{Fe}\left(\mathrm{NH}_{4}\right)_{2}\left(\mathrm{SO}_{4}\right)_{2}, 0.001 \%$; yeast extract, $0.1 \%$; Trypticase, $0.1 \%$; and sodium acetate, $0.41 \%$. In addition, $1 \%$ (vol/vol) vitamin solution and $1 \%(\mathrm{vol} / \mathrm{vol})$ trace element solution were added to the medium (31). The $\mathrm{pH}$ of the medium was adjusted to 7.0 with $\mathrm{HCl}$ before autoclaving. The agar slants used for maintenance of Methanosarcina acetivorans, Methanococcoides methylutens, and Methanolobus tindarius have been described previously $(25 \mathrm{a}, 26)$. Cultures were stored at $20^{\circ} \mathrm{C}$ and transferred monthly.

Large-scale production of cell material. The cells used for extraction of nucleic acids and for cell wall isolation were grown in a 14-liter fermentor modified to operate as a $\mathrm{pH}$ auxostat (22), with acetic acid as the substrate. Strains that 
TABLE 1. Levels of DNA homology and G+C contents ${ }^{a}$

\begin{tabular}{lcrrrrr}
\hline \multirow{2}{*}{ Strain $^{a}$} & $\begin{array}{c}\text { G+C content } \\
(\text { mol\%) }\end{array}$ & \multicolumn{5}{c}{ \% DNA homology with reference } \\
& & MS & 227 & TM-1 & C2A & T3 \\
\hline MS & 39 & $100^{b}$ & 98 & 34 & 27 & \\
227 & 39 & 93 & 100 & 33 & 25 & \\
TM-1 & 42 & 24 & 23 & 100 & 18 & \\
C2A & 42 & 12 & 11 & 14 & 100 & \\
S-6 & 42 & 19 & 16 & 24 & 28 & \\
TMA-10 & 42 & 1 & 1 & 3 & 2 & 4 \\
Tindari 3 & 40 & 2 & 2 & 2 & 2 & 100 \\
\hline
\end{tabular}

${ }^{a}$ Methanosarcina barkeri strains MS and 227, Methanosarcina sp. strain TM-1, Methanosarcina acetivorans strain C2A, Methanosarcina mazei strain S-6, Methanococcoides methylutens strain TMA-10, and Methanolobus tindarius strain Tindari 3.

${ }^{b}$ Homologous values are reported as $100 \%$.

were unable to use acetate were grown on trimethylamine hydrochloride. The trimethylamine hydrochloride concentration was monitored with a gas chromatograph that contained a column $(0.64$ by $183 \mathrm{~cm})$ packed with Carbopak B$4 \%$ Carbowax 20M-0.8\% KOH (Supelco, Inc.). Trimethylamine hydrochloride was added to the culture to replace the depleted substrate. Late exponential phase cultures were harvested with a continuous flow centrifuge as described previously (22) and were stored in liquid nitrogen.

Cell wall preparation. Cell paste was suspended in $15 \mathrm{mM}$ trisodium citrate buffer at $\mathrm{pH} 7.0$ at a ratio of $1: 2(\mathrm{vol} / \mathrm{vol})$ and was passed twice through a French pressure cell at 137 $\mathrm{MPa}$. Cell walls were isolated and purified as described previously (26), with the following modification: whole cells were separated from cell wall fragments by centrifugation in a sucrose gradient. The lysate was layered over a linear (25 to $40 \%$ ) sucrose gradient in citrate buffer $(40 \mathrm{ml})$ in a tube $(25$ by $9.0 \mathrm{~cm}$ ) and centrifuged at $3,000 \times g$ for $15 \mathrm{~min}$. The cell wall fragments that banded near the surface of the gradient were removed with a Pasteur pipette. These cell wall preparations were free of whole cells, as determined by phasecontrast microscopy. Analyses for amino acids and amino sugars were performed as described previously (26).

DNA isolation. The frozen cells were suspended in a 0.15
$\mathrm{M} \mathrm{NaCl}-0.01 \mathrm{M}$ ethylenediaminetetraacetic acid salt solution $(\mathrm{pH} 8.0)$ supplemented with $0.2 \%(\mathrm{vol} / \mathrm{vol})$ ribonuclease $\mathrm{T}_{1}(2,500 \mathrm{U} / \mathrm{ml})(10)$. The DNA was then isolated by one of two methods. Strains that had protein cell walls (strains C2A, TMA-10, and Tindari 3) were lysed by adding $20 \%$ sodium dodecyl sulfate to a final concentration of $1 \%$. The DNA was then isolated by the ethanol precipitation method of Marmur (19). Strains with heteropolysaccharide cell walls (strains MS, 227, TM-1, and S-6) were lysed by one passage through a French pressure cell at $137 \mathrm{MPa}$ into a flask that contained $20 \%$ sodium dodecyl sulfate (final concentration, $1 \%$ ). Then $50 \mu \mathrm{g}$ of proteinase $\mathrm{K}$ per $\mathrm{ml}$ was added to the lysate, and the preparation was incubated at $50^{\circ} \mathrm{C}$ for $1 \mathrm{~h}$. The DNA was then isolated by the hydroxylapatite procedure (10), with the following modification: after the phenol extraction, the preparations were dialyzed in $\mathrm{NaCl}$-ethylenediaminetetraacetic acid buffer to remove the phenol and then treated with ribonuclease before hydroxylapatite extraction. The DNA preparations were stored in $15 \mathrm{mM} \mathrm{NaCl}-1.5 \mathrm{mM}$ sodium citrate $(\mathrm{pH} 7.0)$ at $-20^{\circ} \mathrm{C}$.

RNA isolation. rRNA was isolated as described previously (10). The procedure was modified by suspending the ribonucleic acid (RNA) pellet in $3 \mathrm{M}$ sodium acetate ( $\mathrm{pH}$ 6.0) after the first ethanol precipitation (25). The RNA was centrifuged and suspended in $150 \mathrm{mM} \mathrm{NaCl}-15 \mathrm{mM}$ sodium citrate $(1 \times$ SSC) at $\mathrm{pH} 7.0$ before the second ethanol precipitation. RNA preparations were stored in $1 \times$ SSC supplemented with $0.5 \%$ sodium dodecyl sulfate at $-20^{\circ} \mathrm{C}$.

Competitor rRNA preparations were adjusted to a concentration of $2 \mathrm{mg} / \mathrm{ml}$. The $23 \mathrm{~S}$ and $16 \mathrm{~S}$ rRNA components were isolated by sucrose gradient centrifugation (25) and combined for labeling (11). The purities of the preparations were determined by polyacrylamide gel electrophoresis (2). The preparations were labeled with ${ }^{125} \mathrm{I}$ as described previously (25).

G + C content of DNA. The $\mathrm{G}+\mathrm{C}$ contents of the DNA preparations were determined by thermal denaturation with a spectrophotometer and thermal programmer (Gilford Instrument Laboratories, Inc., Oberlin, Ohio) (10). DNA from Escherichia coli b isolated by both of the methods described above was used as a standard.
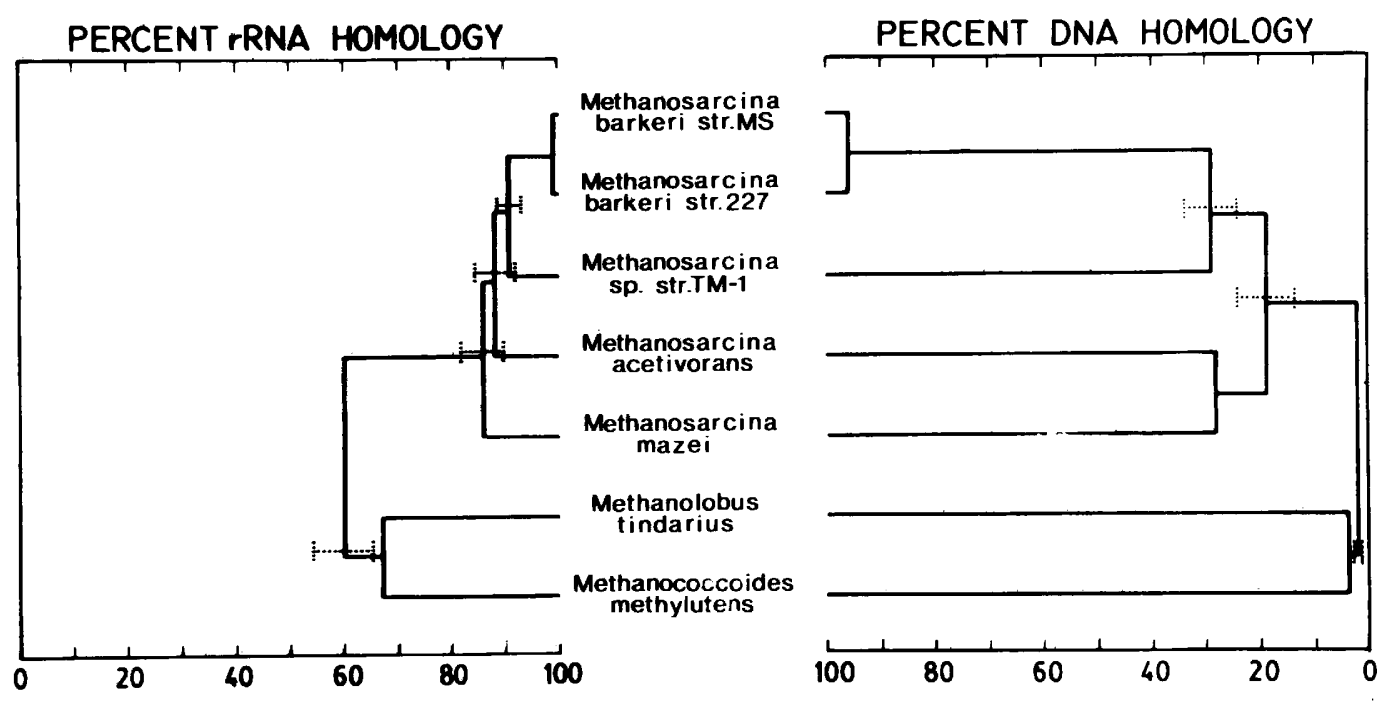

FIG. 1. Dendrograms of the phylogenetic relationships among the methylotrophic methane-producing bacteria. The dendrograms are based on average linkage clustering of the rRNA and DNA percent homology values from Tables 1 and 2 . The standard deviations from the means are indicated by dotted lines. 
TABLE 2. Levels of RNA homology

\begin{tabular}{lrrrrrr}
\hline \multirow{2}{*}{ Strain } & \multicolumn{5}{c}{ \% RNA homology with reference RNA from strain: } \\
\cline { 2 - 7 } & MS & 227 & TM-1 & C2A & TMA-10 & T3 \\
\hline MS & $100^{a}$ & 98 & 88 & 83 & 60 & 50 \\
227 & 100 & 100 & 89 & 84 & 61 & 55 \\
TM-1 & 94 & 93 & 100 & 84 & 58 & 54 \\
C2A & 93 & 91 & 91 & 100 & 69 & 55 \\
S-6 & 92 & 88 & 86 & 79 & 61 & 54 \\
TMA-10 & 68 & 65 & 60 & 61 & 100 & 63 \\
Tindari 3 & 71 & 67 & 62 & 61 & 71 & 100 \\
VPI 2553 & 8 & 8 & 5 & 10 & 9 & 12 \\
VPI 0061 & 10 & 6 & 3 & 11 & 6 & \\
\hline
\end{tabular}

" Homologous values are reported as $100 \%$.

DNA homologies. The $\mathrm{S} 1$ nuclease procedure (10) was used to determine DNA homologies. The reassociation reaction mixtures contained $10 \mu \mathrm{l}(0.025 \mu \mathrm{g})$ of labeled DNA, $50 \mu \mathrm{l}$ $(20 \mu \mathrm{g})$ of unlabeled DNA, and $50 \mu \mathrm{l}$ of a buffer that contained $880 \mathrm{mM} \mathrm{NaCl}$ and $1 \mathrm{mM}$ 4-(2-hydroxyethyl)-1piperazine ethanesulfonic acid (HEPES) at $\mathrm{pH}$ 7.0. Labeled DNA was denatured by heating in boiling water for $5 \mathrm{~min}$. The reaction mixtures were incubated at $62^{\circ} \mathrm{C}$ for $24 \mathrm{~h}$. S1 nuclease-resistant fragments were precipitated with $\mathrm{HCl}(21)$ and collected on type GF/F glass fiber filters (Whatman Ltd., Kent, England). The filters were dried and counted with a gamma scintillation counter (Beckman Instruments, Inc., Irvine, Calif.).

rRNA hybridizations. The competition rRNA hybridization procedure which we used has been described previously (11). The hybridization reaction mixtures contained $10 \mu \mathrm{l}$ $(0.3 \mu \mathrm{g})$ of labeled rRNA, $25 \mu \mathrm{l}(50 \mu \mathrm{g})$ of competitor rRNA, and approximately $4 \mu \mathrm{g}$ of DNA immobilized on a nitrocellulose filter ( 3 by $9 \mathrm{~mm}$ ), all contained in $600 \mathrm{mM} \mathrm{NaCl}-60 \mathrm{mM}$ ethylenediaminetetraacetic acid (4× SSC)-1 mM HEPES buffer ( $\mathrm{pH} 7.0$ ) supplemented with $45 \%$ formamide. The hybridization reaction mixtures were incubated at $50^{\circ} \mathrm{C}$ for $16 \mathrm{~h}$.

rRNA hybrid thermal stabilities. The procedure used to determine the thermal stability profiles of rRNA hybrids with DNA immobilized on nitrocellulose filters has been described previously $(10,11)$. The elution buffer was $4 \times$ SSC-1 mM HEPES ( $\mathrm{pH} 7.0$ ) containing 50\% formamide. The temperatures used to obtain the dissociation profiles were 35 through $85^{\circ} \mathrm{C}$ at $5^{\circ} \mathrm{C}$ increments.

Chemicals. Purified agar and yeast extract were obtained from Difco Laboratories, Detroit, Mich. Trypticase was from BBL Microbiology Systems, Cockeysville, Md. Trimethylamine hydrochloride was from Aldrich Chemical Co., Inc., Milwaukee, Wis. Ribonuclease $A$, ribonuclease $T_{1}$, deoxyribonuclease I, sodium dodecyl sulfate, cysteine hy-

TABLE 3. $\Delta T_{m(e)}$ values of DNA-rRNA thermal stability profiles

\begin{tabular}{lcrrrrr}
\hline \multirow{2}{*}{ Strain } & \multicolumn{5}{c}{$\Delta T_{m(e)}\left({ }^{\circ} \mathrm{C}\right)$ with reference RNA from strain: } \\
\cline { 2 - 7 } & \multicolumn{1}{c}{ MS } & \multicolumn{1}{c}{227} & \multicolumn{1}{c}{ TM-1 } & C2A & TMA-10 & T3 \\
\hline MS & $68.0^{a}$ & \multicolumn{1}{c}{0} & 5.3 & 3.8 & 12.9 & 8.0 \\
227 & 0 & 68.0 & 5.0 & 3.8 & 12.7 & 9.0 \\
TM-1 & 3.9 & 4.0 & 70.5 & 4.5 & 12.4 & 8.5 \\
C2A & 2.4 & 2.1 & 4.2 & 68.6 & 12.3 & 8.1 \\
S-6 & 2.9 & 2.9 & 4.2 & 3.4 & 12.2 & 8.2 \\
TMA-10 & 9.9 & 10.8 & 9.7 & 12.3 & 70.6 & 6.0 \\
Tindari 3 & 9.7 & 10.0 & 9.7 & 10.9 & 7.2 & 64.6 \\
\hline
\end{tabular}

${ }^{a}$ Homologous values are reported as midpoint temperatures. drochloride, and all organic buffers and vitamins were from Sigma Chemical Co., St. Louis, Mo. Acrylamide, bisacrylamide, and DNA grade hydroxylapatite were from Bio-Rad Laboratories, Richmond, Calif. ${ }^{125}$ INa was from New England Nuclear Corp., Boston, Mass. All other chemicals were reagent grade.

\section{RESULTS AND DISCUSSION}

The $\mathrm{G}+\mathrm{C}$ contents of seven strains of methylotrophic methane-producing bacteria (Table 1) were determined with standards which were isolated by using the same technique that was used for the DNA preparations assayed. The values for Methanosarcina barkeri strains MS and 227, Methanosarcina sp. strain TM-1, and Methanosarcina mazei were consistently 1 mol\% lower than the values obtained by the buoyant density technique (R. Mah, personal communication). The G+C content of Methanolobus tindarius was 6 mol\% lower than the value of $45.9 \mathrm{~mol} \%$ previously reported (15), but the reason for this discrepancy is not known.

Levels of DNA homology (Table 1) were determined with ${ }^{125}$ I-labeled DNAs from five reference strains. A dendrogram (Fig. 1) prepared from the DNA homology values by average linkage clustering showed two distinct groups with only $2 \%$ DNA homology. Methanosarcina sp. strain TM-1, Methanosarcina acetivorans, and Methanosarcina mazei each had less than $30 \%$ homology with all of the other strains tested. Methanococcoides methylutens and Methanolobus tindarius had no significant DNA homology either with one another or with the other strains tested. These results indicated that the seven strains tested could be separated into six species (9). Inclusion of strain 227 in the species Methanosarcina barkeri based on a DNA homology value of $96 \%$ is consistent with the conclusion of Balch et al. (1), who used rRNA oligonucleotide cataloging. All of the other strains showed levels of DNA homology with each other that were well below $60 \%$, which is the accepted value for division at the genospecies level (9).

Cross-hybridization values of rRNAs obtained by the competition method from the seven strains were determined with ${ }^{125}$ I-labeled rRNAs from six reference strains (Table 2). The values for Bacteroides fragilis VPI 2553 (parent strain of strain ATCC 25285) and Bacteroides uniformis VPI 0061 (parent strain of strain ATCC 8492) rRNAs, which were

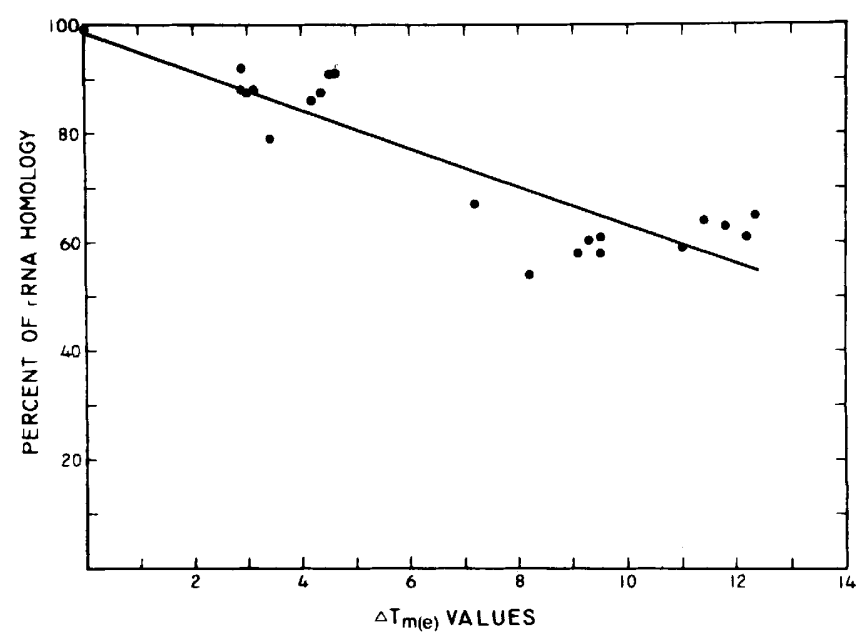

FIG. 2. Relationship of rRNA homology values to $\Delta T_{m(e)}$ values. Data from Tables 2 and 3. 
TABLE 4. Phenotypic characteristics of the methylotrophic methane-producing bacteria ${ }^{a}$

\begin{tabular}{|c|c|c|c|c|c|c|}
\hline \multirow{2}{*}{ Strain } & \multicolumn{2}{|c|}{ Growth with: ${ }^{b}$} & \multirow{2}{*}{$\begin{array}{l}\text { Optimum } \\
\text { growth } \\
\text { temp }\left({ }^{\circ} \mathrm{C}\right)\end{array}$} & \multirow{2}{*}{$\begin{array}{c}\text { Cell wall } \\
\text { composition }\end{array}$} & \multirow{2}{*}{$\begin{array}{l}\mathrm{C}_{20} \text { phytanyl } \\
\text { glycerol } \\
\text { ethers }\end{array}$} & \multirow{2}{*}{$\begin{array}{l}\text { Flagella } \\
\text { or } \\
\text { fimbriae }\end{array}$} \\
\hline & $\mathrm{H}_{2}-\mathrm{CO}_{2}$ & Acetate & & & & \\
\hline$\overline{\mathrm{MS}}$ & $t^{c}$ & + & 35 & $\mathrm{H}^{d}$ & + & - \\
\hline 227 & + & + & 35 & $\mathrm{H}$ & $\mathrm{ND}^{e}$ & - \\
\hline TM-1 & $+1-$ & + & 50 & $\mathrm{H}$ & ND & - \\
\hline $\mathrm{C} 2 \mathrm{~A}$ & - & + & 40 & $\mathbf{P}$ & ND & + \\
\hline S-6 & $+1-$ & + & 40 & $\mathrm{H}$ & ND & - \\
\hline TMA-10 & - & - & 35 & $P$ & + & + \\
\hline Tindari 3 & - & - & 25 & $\mathrm{P}$ & ND & + \\
\hline
\end{tabular}

${ }^{a}$ Data obtained from references $1,15,16,18,25 a, 26$, and 35 and from $\mathrm{S} . \mathrm{H}$. Zinder (personal communication).

${ }^{b}$ In addition to methanol and methylated amines.

$c+$, Positive; -, negative; $+/-, \mathrm{H}_{2}-\mathrm{CO}_{2}$ used slowly.

${ }^{d} \mathrm{H}$, Heteropolysaccharide; $\mathrm{P}$, protein.

ND, Not determined.

included as heterologous controls, were below $12 \%$. Thermal stability results are reported as midpoint temperatures and differences in midpoint temperatures $\left[\Delta T_{m(e)}\right]$ (Table 3). The rRNA homology values obtained by the competition technique were compared with the $\Delta T_{m(e)}$ values (correlation coefficient, 0.89) (Fig. 2). A similar correlation coefficient was observed for the two methods with the eubacteria (11). The oligonucleotide sequence similarity values $\left(S_{\mathrm{AB}}\right)$ of Methanosarcina barkeri strain MS relative to Methanosarcina mazei $\left(S_{\mathrm{AB}}, 0.8\right)(17)$ and Methanococcoides methylutens $\left(S_{\mathrm{AB}}, 0.52\right)(\mathrm{C}$. Woese, personal communication) are in agreement with the rRNA homology values (Table 2 ).

A dendrogram of the rRNA homology values from Table 2 is shown in Fig. 1. The results of rRNA hybridization experiments (Fig. 1) indicated that there were the following two distinct groups above the species level: group I, which included Methanosarcina barkeri, Methanosarcina sp. strain TM-1, Methanosarcina acetivorans, and Methanosarcina mazei, and group II, which included Methanolobus tindarius and Methanococcoides methylutens. Phenotypic characteristics of the strains are compared in Table 4. Although group I varied with respect to the ability to use $\mathrm{H}_{2}$ $\mathrm{CO}_{2}$, all species in this group used acetate as a substrate. The inability of group II species to use acetate appeared to be the only phenotypic characteristic that divides the two groups. The apparent morphologies do not support the division since morphovar III was expressed by both groups. In addition, a methylotrophic isolate that is unable to utilize acetate and expresses mornhovars I and III and communal cysts has been described (34). Other phenotypic characteristics cannot be used to divide the two groups (Table 4).

An apparent anomaly is the presence of species with different cell wall types within the genus Methanosarcina (Table 4). All of the freshwater strains of Methanosarcina studied have rigid, thick cell walls composed of galactosamine, glucose, mannose, and glucuronic acid or galacturonic acid in varying proportions (12). The marine species, Methanosarcina acetivorans, has thin cell walls $(10 \mathrm{~nm})$ composed of protein subunits (25a). Cell wall structure is a conserved characteristic which has coincided with phylogenetic divisions at the genus level in previous studies of the archaeobacteria $(1,12)$. Despite the gross morphological and chemical differences between heteropolysaccharide and protein cell walls, the results of immunological fingerprinting (3, 4) indicated that there are common antigenic determinants between Methanosarcina acetivorans and species with he- teropolysaccharide cell walls (E. Conway de Macario, personal communication). Likewise, Methanolobus tindarius and Methanococcoides methylutens, which also have protein cell walls, reacted as strongly or more strongly with heteropolysaccharide cell wall species than with each other. One possible explanation for these results is that all members of group I possess a protein cell wall with a heteropolysaccharide outer layer. Zeikus and Bowen (32) described the cell wall of Methanosarcina barkeri strain MS in electron micrographs as having laminated amorphous outer layers which were attached to an electron-dense layer adjacent to the cell membrane. A 10-nm electron-dense inner layer, which is the thickness of a protein cell wall $(15,25 \mathrm{a}, 26)$, was also reported by Zhilina (33) in thin-section electron micrographs of Methanosarcina sp. Although previous investigators observed no or only trace amounts of amino acids in heteropolysaccharide cell wall preparations $(12,13 ; \mathrm{S}$. F. Hurst, R. W. Robinson, and A. S. Bleiweis, Abstr. Annu. Meet. Am. Soc. Microbiol. 1982, J10, p. 92), treatment of the cell wall preparations included incubation with trypsin or sodium dodecyl sulfate, which would have completely solubilized a protein cell wall layer (14). Acid-hydrolyzed cell wall preparations contained a significant proportion of amino acids (17.32\% of the total volatile mass) and an amino acid distribution (Table 5) similar to that in protein cell walls (14, 20, 25a, 26, 28, 30). Cysteine, aspartic acid, and glutamic acid were predominant. The ash content of the preparations was $14.4 \%$ of the total dry weight; $17.0 \%$ of the volatile fraction was recovered as galactosamine, and $0.54 \%$ was recovered as glucosamine. The high proportion of cysteine in the cell wall preparation of Methanosarcina barkeri (Table 5 ) has not been reported previously in protein cell walls. The volatile mass not accounted for $(65 \%)$ may contain uronic acids and neutral sugars (S. F. Hurst and A. S. Bleiweiss, Abstr. Annu. Meet. Am. Soc. Microbiol. 1984, I81, p. 135), as well as residual water. These results suggest that methanogenic bacteria with heteropolysaccharide cell walls also

TABLE 5. Amino acid and amino sugar content of a hydrolyzed cell wall preparation of Methanosarcina barkeri strain 227

\begin{tabular}{lcc}
\hline Compound & $\begin{array}{c}\text { Concn }(\mu \mathrm{mol} / \\
\mathrm{mg}, \mathrm{dry} \text { wt })\end{array}$ & Molar ratio $^{a}$ \\
\hline Amino acids & 181.2 & \\
Cys & 124.3 & 3.08 \\
Asp & 101.2 & 2.11 \\
Glu & 100.8 & 1.72 \\
Thr & 86.7 & 1.71 \\
Ser & 77.8 & 1.47 \\
Gly & 76.8 & 1.32 \\
Ala & 59.3 & 1.30 \\
Leu & 58.9 & 1.01 \\
His & 52.3 & 1.00 \\
Val & 45.7 & 0.89 \\
Lys & 41.4 & 0.77 \\
Ile & 39.4 & 0.71 \\
Pro & 21.3 & 0.67 \\
Met & 19.1 & 0.36 \\
Tyr & 18.9 & 0.32 \\
Phe & 17.0 & 0.32 \\
Arg & ND & 0.29 \\
Trp & & ND \\
Amino sugars & 409.8 & \\
Galactosamine & 25.9 & ND \\
Glucosamine & & ND \\
\hline
\end{tabular}

${ }^{a}$ Based on a value of 1.00 for histidine.

${ }^{b} \mathrm{ND}$, Not determined. 


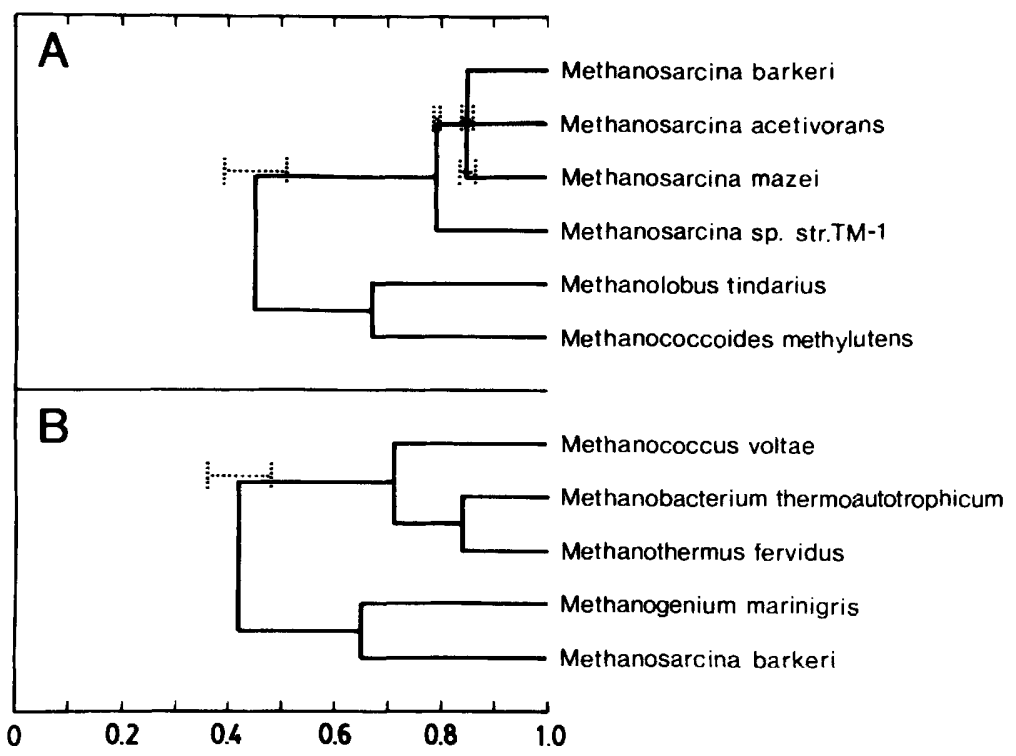

FIG. 3. Dendrograms of the relationships among the methanogenic bacteria based on $\Delta T_{m(e)}$ values from this study (A) and from the study of Tu et al. (29) (B). Data from both studies were normalized by using a value of $20^{\circ} \mathrm{C}$ for the maximum heterologous $\Delta T_{m(e)}$ value. The phylogenetic relationships are expressed as fractional $\Delta T_{m(e)}$ values ranging from 0.0 to 1.0. Fractional $\Delta T_{m(e)}=20-\Delta T_{m(e)} / 20$. The standard deviations from the means are indicated by dotted lines.

have an inner protein cell wall layer. This hypothesis is supported by the fact that all other known species in the order Methanomicrobiales have protein cell walls (12). Since no single-step mutations are known which lead to an altered cell wall type (24), Methanosarcina acetivorans may have lost the ability to produce the heteropolysaccharide outer layer of its cell wall. Alternatively, nonmarine species may have developed the heteropolysaccharide for osmotic protection.

As a result of these observations we propose that the family Methanosarcinaceae be emended to include the species Methanosarcina acetivorans, Methanolobus tindarius, and Methanococcoides methylutens, as described below.

Family II, Methanosarcinaceae. Methanosarcinaceae Balch and Wolfe 1979 (emend.) (Me.tha.no.sar.cin.a'ce.ae. M.L. fem. n. Methanosarcina type genus of the family; -aceae ending to denote family; M.L. fem. pl. n. Methanosarcinaceae the Methanosarcina family.) Spherical or pleomorphic cells 1.0 to $2.5 \mu \mathrm{m}$ in diameter. Members of this family express one or more of the following three cellular arrangements: morphovar $I$ is an aggregation of cocci, up to $100 \mu \mathrm{m}$ in diameter; morphovar II is a smaller aggregation of cells, up to $30 \mu \mathrm{m}$ in diameter; and morphovar III cells are arranged singly. Some species also form communal cysts of several single cells within a common envelope. Cell division planes are irregular. A species may have a protein cell wall $10 \mathrm{~nm}$ thick which has a negative Gram reaction or a cell wall layer composed of heteropolysaccharide that stains gram positive or gram variable. Cells are nonmotile mesophiles to thermophiles. Energy for growth comes from the oxidation of $\mathrm{H}_{2}$ with the reduction of $\mathrm{CO}_{2}$ to methane or from metabolism of methanol, methylated amines (methylamine, dimethylamine, trimethylamine, or ethyldimethylamine), or acetate with formation of methane and $\mathrm{CO}_{2}$ as end products; ammonia is produced from amine degradation. Gas-vacuolated forms have been reported.

We propose that rRNA homology groups I and II be divided at the genus level based on a rRNA homology level of $60 \%$ (Table 1) and an $S_{\mathrm{AB}}$ value of 0.52 between Methanosarcina barkeri strain MS and Methanococcoides methylutens (Woese, personal communication). Although these values are higher than those most used to divide genera of eubacteria $(6,24)$, they fall within the genus-species division value for the methanogenic bacteria proposed by Balch et al. (1). This division is further supported by the DNA-rRNA hybridization data of $\mathrm{Tu}$ et al. (29). The midpoint temperatures of the thermal melting curves for DNA-rRNA hybrids from that study were normalized by using a value of $20^{\circ} \mathrm{C}$ as the maximum heterologous $\Delta T_{m(e)}$ value (11). The phylogenetic relationships are expressed as the fractional $\Delta T_{m(e)}$ values between heterologous $(0.0)$ and homologous (1.0) strains in Fig. 3. The fractional $\Delta T_{m(e)}$ value between group I and group II was lower than most values between other genera of methane-producing bacteria. In addition, species in group I could use acetate, but those in group II could not. All species in group I, which includes Methanosarcina

TABLE 6. Phenotypic differences between Methanolobus tindardius strain Tindari 3 and Methanococcoides methylutens strain TMA-10 ${ }^{a}$

\begin{tabular}{|c|c|c|c|c|c|c|c|}
\hline Species & Source & $\begin{array}{c}\text { Flagellum } \\
\text { or } \\
\text { fimbriae }\end{array}$ & $\begin{array}{l}\text { Internal } \\
\text { membranes }\end{array}$ & $\begin{array}{l}\text { Uniform } \\
\text { inclusions }\end{array}$ & $\begin{array}{l}\text { Vitamins } \\
\text { required }\end{array}$ & $\begin{array}{l}\text { Maximum } \\
\text { growth } \\
\text { temp }\left({ }^{\circ} \mathrm{C}\right)\end{array}$ & $\begin{array}{l}\text { Optimum } \\
\text { growth } \\
\text { temp }\left({ }^{\circ} \mathrm{C}\right)\end{array}$ \\
\hline $\begin{array}{l}\text { Methanolobus } \\
\text { tindarius }\end{array}$ & $\begin{array}{l}\text { Marsh } \\
\text { pond }\end{array}$ & + & + & + & - & 45 & 25 \\
\hline $\begin{array}{l}\text { Methanococcoides } \\
\text { methylutens }\end{array}$ & $\begin{array}{l}\text { Marine } \\
\text { canyon }\end{array}$ & + & - & - & + & 35 & 35 \\
\hline
\end{tabular}

\footnotetext{
"Data obtained from references 15 and 26
} 
barkeri (18), Methanosarcina acetivorans (25a), Methanosarcina mazei (16), and Methanosarcina sp. strain TM-1 (35), are in the genus Methanosarcina as described by Balch et al. (1).

The group II strains showed virtually no DNA homology (4\%), which indicates that they are separate species. The different $\mathrm{G}+\mathrm{C}$ values (Table 1 ) and phenotypic characteristics (Table 6) support this conclusion. The level of rRNA homology between Methanolobus tindarius and Methanococcoides methylutens was only $7 \%$ greater than the levels of rRNA homology between these two species and Methanosarcina (Fig. 1). In addition, when fractional $\Delta T_{m(e)}$ values obtained in this study are compared with values obtained by Tu et al. (29), the value between Methanococcoides methylutens and Methanolobus tindarius is lower than the values between other genera of the methanogenic bacteria (Fig. 3). Although Methanolobus tindarius (15) and Methanococcoides methylutens (26) are phenotypically similar (Table 6), results of this study suggest that they are phylogenetically distant. As more methylotrophic strains become available and their phylogenies are determined, the current division may become less distinct, and merging of these genera may be warranted. The maintenance of separate genera may also be impractical for identification purposes if more distinguishing phenotypic characteristics are not found in other strains. The genera Methanolobus and Methanococcoides have been described elsewhere $(15,26)$.

Despite the morphological diversity among the methylotrophic methane-producing bacteria, these organisms appear to be closely related at the level of rRNA homology. As the phylogenetic relationships of more strains are determined, the generic division observed in this study may become more or less pronounced, warranting changes in the proposed divisions. The phylogenetic divisions obtained with DNArRNA and DNA-DNA hybridization techniques showed good agreement with phenotypic characteristics and complemented the oligonucleotide sequencing data of Balch et al. (1) for the methanogenic bacteria.

\section{ACKNOWLEDGMENTS}

We thank M. P. Bryant, R. A. Mah, and K. O. Stetter for the strains used in this study. We thank E. Conway de Macario, New York State Department of Health, for the immunological fingerprinting of Methanosarcina acetivorans and Methanococcoides methylutens. We thank D. R. Bevins and B. H. Combs, Department of Biochemistry and Nutrition, Virginia Polytechnic Institute and State University, for the amino acid analyses. We thank C. R. Woese, University of Illinois, for the 16S rRNA oligonucleotide catalog of Methanococcoides methylutens. We thank W. E. C. Moore and E. P. Cato for critical review of the manuscript. We are especially grateful to S. H. Zinder, Cornell University, and R. A. Mah, University of California at Los Angeles, for helpful discussions.

This investigation was supported by grant 5092-260-0710 from the Gas Research Institute, Basic Research, and by grant DEB 8001191 from the National Science Foundation.

\section{LITERATURE CITED}

1. Balch, W. E., G. E. Fox, L. J. Magrum, C. R. Woese, and R. S. Wolfe. 1979. Methanogens: reevaluation of a unique biological group. Micribiol. Rev. 43:260-296.

2. Bishop, D. H. L., J. R. Claybrook, and S. Spiegelman. 1967. Electrophoretic separation of viral nucleic acids on polyacrylamide gels. J. Mol. Biol. 26:373-387.

3. Conway de Macario, E., A. J. L. Macario, M. C. Magariños, H. König, and O. Kandler. 1983. Dissecting the antigenic mosaic of the archaebacterium Methanobacterium thermoautotrophicum by monoclonal antibodies of defined molecular specificity.
Proc. Natl. Acad. Sci. U.S.A. 80:6346-6350.

4. Conway de Macario, E., A. J. L. Macario, and M. J. Wolin. 1982. Specific antisera and immunological procedures for characterization of methanogenic bacteria. J. Bacteriol. 149:320 328.

5. Douglas, C., F. Achatz, and A. Böck. 1980. Electrophoretic characterization of ribosomal proteins from methanogenic bacteria. Zentralbl. Bakteriol. Parasitenkd. Infektionskr. Hyg. Abt. 1 Orig. Reihe C 1:1-11.

6. Fox, G. E., E. Stackebrandt, R. B. Hespell, J. Gibson, J. Maniloff, T. A. Dyer, R. S. Wolfe, W. E. Balch, R. S. Tanner, L. J. Magrum, L. B. Zablen, R. Blakemore, R. Gupta, L. Bonen, B. J. Lewis, D. A. Stahl, K. R. Luehrsen, K. N. Chen, and C. R. Woese. 1980. The phylogeny of prokaryotes. Science 209:457463 .

7. Hungate, R. E. 1969. A roll tube method for cultivation of strict anaerobes, p. 117-132. In J. R. Norris and D. W. Ribbons (ed.), Methods in microbiology, vol. 3B. Academic Press, Inc., New York.

8. Huser, B. A., K. Wuhrmann, and A. J. B. Zehnder. 1982. Methanothrix soehngenii gen. nov. sp. nov., a new acetotrophic non-hydrogen-oxidizing methane bacterium. Arch. Microbiol. 132:1-9.

9. Johnson, J. L. 1973. The use of nucleic acid homologies in the taxonomy of anaerobic bacteria. Int. J. Syst. Bacteriol. 23:308315 .

10. Johnson, J. L. 1981. Genetic characterization, p. 450-472. In P. Gerhardt (ed.), Manual of methods for general bacteriology. American Society for Microbiology, Washington, D.C.

11. Johnson, J. L., and B. Harich. 1983. Comparisons of procedures for determining ribosomal ribonucleic acid similarities. Curr. Microbiol. 9:111-120.

12. Kandler, O. 1982. Cell wall structures and their phylogenetic implications. Zentralbl. Bakteriol. Parasitenkd. Infektionskr. Hyg. Abt. 1 Orig. Reihe C 3:149-160.

13. Kandler, O., and H. Hippe. 1977. Lack of Peptidoglycan in the cell walls of Methanosarcina barkeri. Arch. Microbiol. 113:5760.

14. Kandler, O., and H. König. 1978. Chemical composition of the peptidoglycan-free cell walls of methanogenic bacteria. Arch. Microbiol. 118:141-152.

15. König, H., and K. O. Stetter. 1982. Isolation and characterization of Methanolobus tindarius sp. nov., a coccoid methanogen growing only on methanol and methylamines. Zentralbl. Bakteriol. Parasitenkd. Infektionskr. Hyg. Abt. 1 Orig. Reihe C 3:478-490.

16. Mah, R. A. 1980. Isolation and characterization of Methanococcus mazei. Curr. Microbiol. 3:321-326.

17. Mah, R. A., and D. A. Kuhn. 1984. Transfer of the type species of the genus Methanococcus to the genus Methanosarcina, naming it Methanosarcina mazei (Barker 1936) comb. nov. et. emend. and conservation of the genus Methanococcus (Approved Lists 1980) with Methanococcus vannielii (Approved Lists 1980) as the type species. Int. J. Syst. Bacteriol. 34:263265 .

18. Mah, R. A., M. R. Smith, and L. Baresi. 1978. Studies on an acetate-fermenting strain of Methanosarcina. Appl. Environ. Microbiol. 35:1174-1184.

19. Marmur, J. 1961. A procedure for the isolation of deoxyribonucleic acid from micro-organisms. J. Mol. Biol. 3:208-218.

20. Marshall, C. L., A. J. Wicken, and A. D. Brown. 1969. The outer layer of the cell envelope of Halobacterium halobium. Can. J. Biochem. 47:71-74.

21. Rigby, P. W. J., M. Dieckmann, C. Rhodes, and P. Berg. 1977. Labeling deoxyribonucleic acid to high specific activity in vitro by nick translation with DNA polymerase I. J. Mol. Biol. 113:237-251.

22. Schauer, N. L., and J. G. Ferry. 1980. Metabolism of formate in Methanobacterium formicicum. J. Bacteriol. 142:800-807.

23. Schleifer, K. H., and O. Kandler. 1972. Peptidoglycan types of bacterial cell walls and their taxonomic implications. Bacteriol. Rev. 36:407-477.

24. Schleifer, K. H., and E. Stackebrandt. 1983. Molecular system- 
atics of prokaryotes. Annu. Rev. Microbiol. 37:143-187.

25. Selin, Y. M., B. Harich, and J. L. Johnson. 1983. Preparation of labeled nucleic acids (nick translation and iodination) for DNA homology and rRNA hybridization experiments. Curr. Microbiol. 8:127-132.

25a.Sowers, K. R., S. F. Baron, and J. G. Ferry. 1984. Methanosarcina acetivorans $\mathrm{sp}$. nov., an acetotrophic methane-producing bacterium isolated from marine sediments. Appl. Environ. Microbiol. 47:971-978.

26. Sowers, K. R., and J. G. Ferry. 1983. Isolation and characterization of a methylotrophic marine methanogen, Methanococcoides methylutens gen. nov., sp. nov. Appl. Environ. Microbiol. 45:684-690.

27. Stackebrandt, E., E. Seewaldt, W. Ludwig, K.-H. Schleifer, and B. A. Huser. 1982. The phylogenetic position of Methanothrix soehngenii. Elucidation by a modified technique of sequencing oligonucleotides from 16S RNA. Zentralbl. Bakteriol. Parasitenkd. Infektionskr. Hyg. Abt. 1 Orig. Reihe C 3:90-100.

28. Steensland, H., and H. Larsen. 1969. A study of the cell envelope of the halobacteria. J. Gen. Microbiol. 55:325-336.

29. Tu, J., D. Prangishvilli, H. Huber, G. Wildgruber, W. Zillig, and K. O. Stetter. 1982. Taxonomic relations between archaebacteria including 6 novel genera examined by cross hybridization of DNAs and 16S rRNAs. J. Mol. Evol. 18:109-114.

30. Weiss, R. L. 1974. Subunit cell wall of Sulfolobus acidocaldarius. J. Bacteriol. 118:275-284.

31. Wolin, E. A., M. J. Wolin, and R. S. Wolfe. 1963. Formation of methane by bacterial extracts. J. Biol. Chem. 238:2882-2886.

32. Zeikus, J. G., and V. G. Bowen. 1975. Comparative ultrastructure of methanogenic bacteria. Can. J. Microbiol. 21:121-129.

33. Zhilina, T. N. 1971. The fine structure of Methanosarcina. Microbiology (USSR) 40:674-680.

34. Zhilina, T. N. 1983. A new obligate halophilic methane-producing bacterium. Microbiology (USSR) 52:375-382.

35. Zinder, S. H., and R. A. Mah. 1979. Isolation and characterization of a thermophilic strains of Methanosarcina unable to use $\mathrm{H}_{2}-\mathrm{CO}_{2}$ for methanogenesis. Appl. Environ. Microbiol. 38:9961008 . 